\title{
THE NATURE OF THE ARTERIAL HYPERTENSION PRODUCED IN NORMAL SUBJECTS BY THE ADMINISTRATION OF ANGIOTONIN ${ }^{1}$
}

\author{
By ROBERT W. WILKINS AND CHARLES N. DUNCAN \\ (From the Evans Memorial, and the Massachusetts Memorial Hospitals, Department of \\ Medicine, Boston University School of Medicine, Boston)
}

(Received for publication July 21, 1941)

It is now established that sustained arterial hypertension can be produced experimentally in animals by interference with the blood supply of the kidney $(1,2,3)$. Furthermore, this experimental hypertension can be relieved either by removing the interference or by excising the entire offended kidney $(3,4)$. There seems little doubt that this type of hypertension has a clinical counterpart in the naturally occurring hypertension of certain patients whose arterial pressure has been lowered after removal of an "ischemic" kidney (5 to 9 ).

It has also been demonstrated that the experimental hypertension associated with renal "ischemia " is humoral in nature $(4,10,11)$, and probably due to the release of abnormal amounts of pressor substances by the offended kidney (11, $12,13)$. This revived interest in the original work of Tigerstedt and Bergman (14) who in 1898 prepared from kidneys a pressor extract which they called " Renin." Modern methods of purification and analysis have revealed that the pressor agent in Renin is probably an enzyme (15, 16) which reacts with a pseudoglobulin fraction of blood to form a vasoconstrictor substance called "Angiotonin" (17) or "Hypertensin" (18).

Evidence is accumulating that a vasoconstrictor substance similar to, if not identical with, “ Angiotonin" or "Hypertensin" is present in abnormal amounts in the blood of animals with experimentally produced renal "ischemia", and of certain patients with naturally occurring hypertension $(18,19,20)$. Therefore, it has been postulated that in these instances Angiotonin may be the humoral agent responsible for the elevated arterial pressure. These considerations made it seem essential to determine whether the adminis-

1 Presented before The Society for Clinical Investigation at the annual meeting at Atlantic City, May 5, 1941. tration of Angiotonin to normal subjects would produce arterial hypertension similar to that observed clinically in human cases.

\section{METHODS}

The Angiotonin 2 was administered intravenously, either full strength in single injections ranging from $0.1 \mathrm{cc}$. to 2 cc., or as a 10 per cent solution (in saline) by constant infusion at rates up to $5 \mathrm{cc}$. per minute.

Arterial pressure was determined by the Hamilton manometer (21) in the femoral artery, or by the usual auscultatory method in the brachial artery. Venous pressure was measured in the antecubital vein either by the Hamilton manometer or by the method of Moritz and von Tabora (22). Pulse rate was counted from one of the several tracings obtained.

Temperature of the skin was measured by thermal junctions lightly attached to the skin by adhesive strips. Usually the pads of the fingers and toes, and occasionally points on the face, chest or forearms were selected for temperature measurements. Rectal temperature was determined by a thermal junction inserted at least $5 \mathrm{~cm}$. above the internal rectal sphincter. The galvanometer allowed the detection of changes of $0.1^{\circ} \mathrm{C}$. The room was draught-free and was maintained at a temperature as constant as possible.

Blood flow in the hand, forearm or calf was measured plethysmographically $(23,24)$. Measurements were made both in the normal resting condition, and also after full local vasodilatation had been induced by a 5 -minute period of arterial occlusion (25). The latter type of measurements have been termed "reactive-hyperemia blood flows." Three minutes were allowed for recovery between each 5-minute period of arterial occlusion when such measurements were being made.

Circulation time was determined by the sodium cyanide method (26). Cardiac output was estimated in both the supine and erect positions on the ballistocardiographs of Dr. Isaac Starr (27), who very kindly made the records and did the calculations. Spinal fluid pressure, vital capacity, electrocardiograms, teleoroentgenograms and kymograms were obtained by the usual techniques. Dur-

2 The Angiotonin was prepared and generously supplied by Dr. Irvine H. Page and his co-workers at the Lilly Laboratory for Clinical Research, Indianapolis, Indiana. 


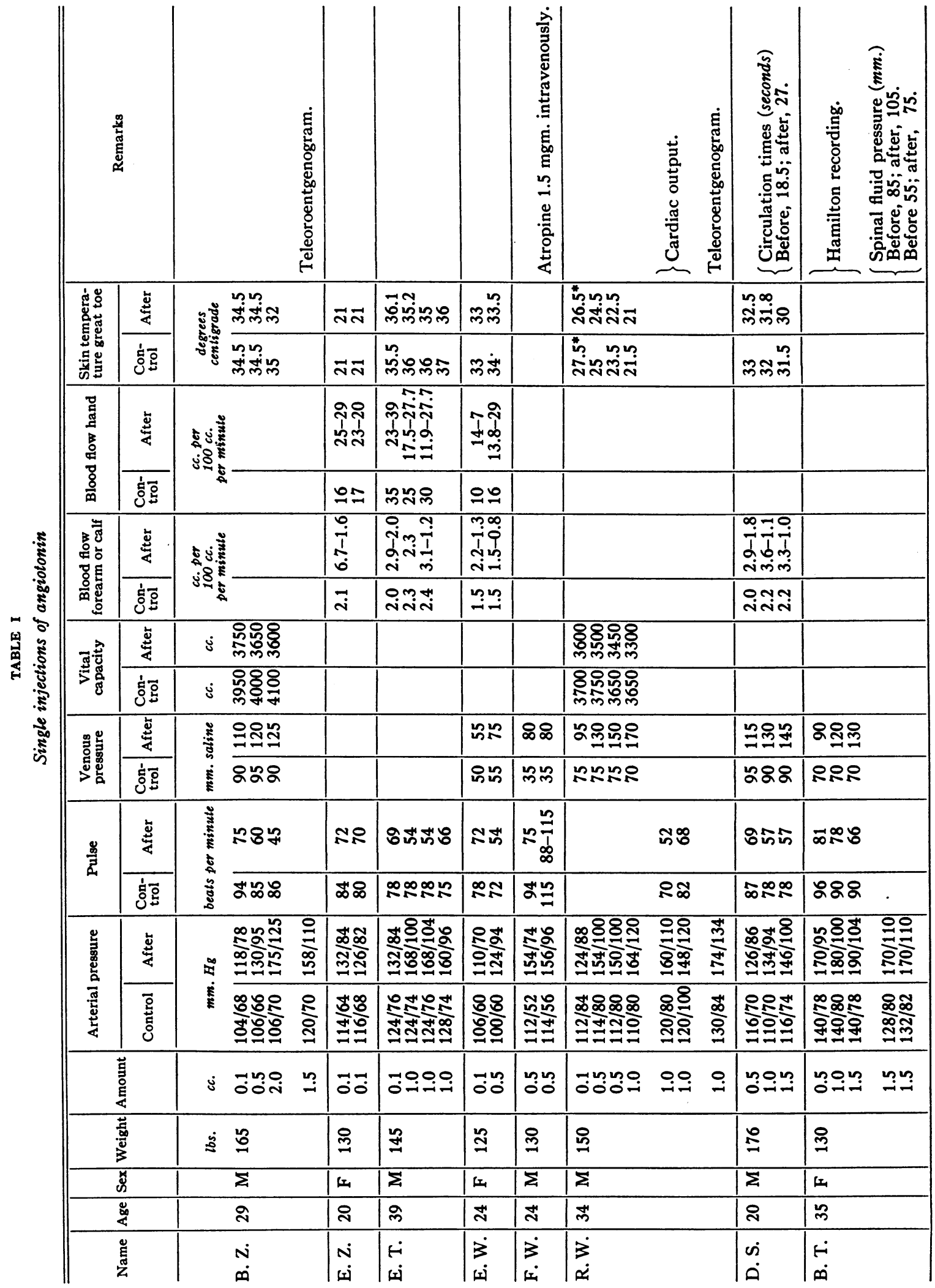




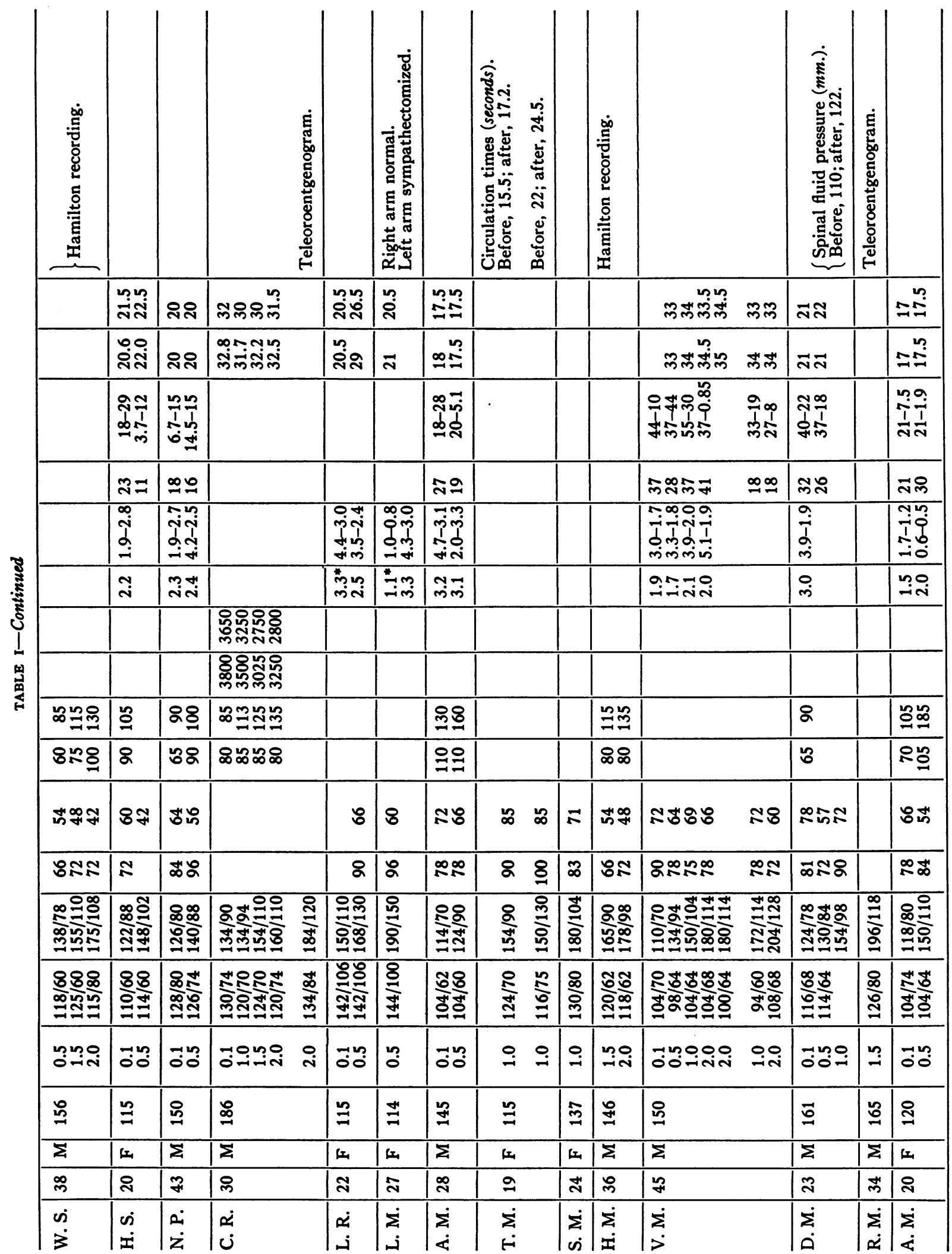




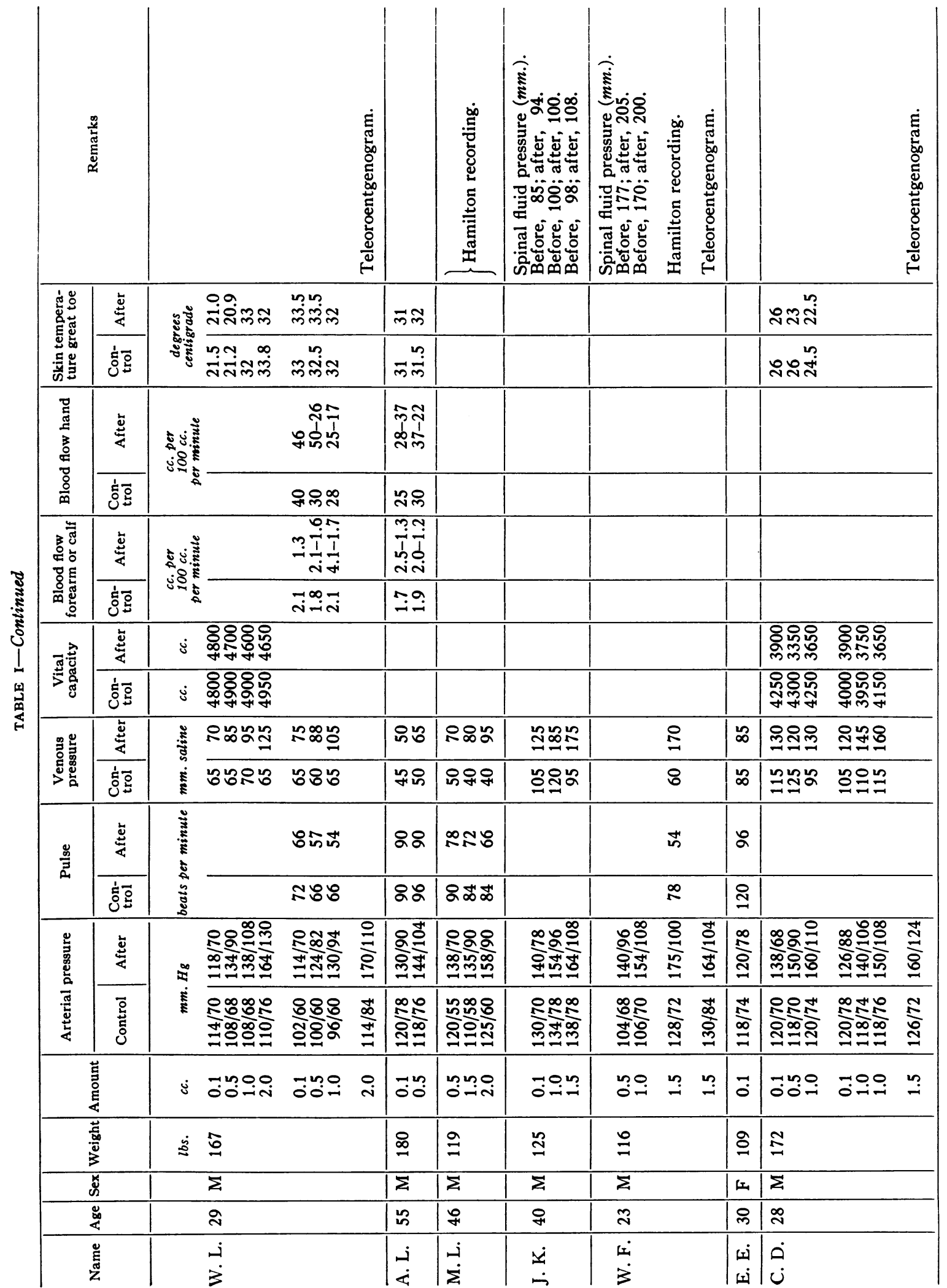




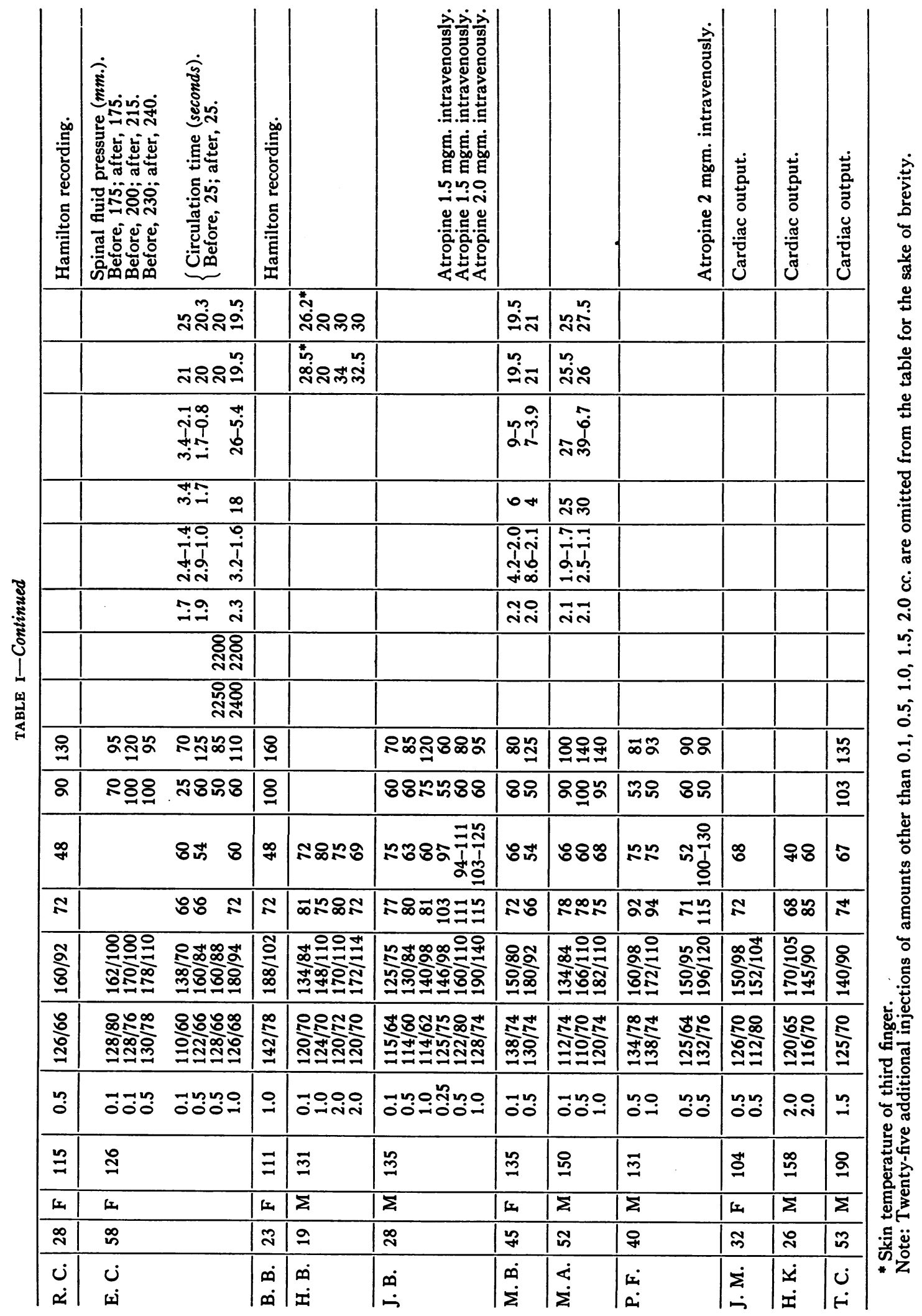


TABLE II

Intravenous infusions of 10 per cent solution of angiotonin

\begin{tabular}{|c|c|c|c|c|c|c|c|c|c|c|c|c|c|c|c|c|c|c|c|c|}
\hline \multirow{3}{*}{ 苋 } & \multirow[b]{3}{*}{$\frac{0}{4}$} & \multirow[b]{3}{*}{ ๗ั้ } & \multirow{3}{*}{ 壱 } & \multirow{3}{*}{ 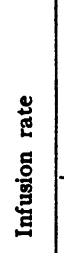 } & \multirow{2}{*}{\multicolumn{2}{|c|}{$\begin{array}{l}\text { Arterial } \\
\text { pressure }\end{array}$}} & \multirow{2}{*}{\multicolumn{2}{|c|}{ Pulse }} & \multirow{2}{*}{\multicolumn{2}{|c|}{$\begin{array}{l}\text { Venous } \\
\text { pressure }\end{array}$}} & \multicolumn{4}{|c|}{$\begin{array}{c}\text { Cold test } \\
\text { arterial pressure }\end{array}$} & \multicolumn{4}{|c|}{ Blood flow } & \multirow{2}{*}{\multicolumn{2}{|c|}{$\begin{array}{l}\begin{array}{c}\text { Skin tem- } \\
\text { perature }\end{array} \\
\text { Great toe }\end{array}$}} \\
\hline & & & & & & & & & & & \multicolumn{2}{|c|}{ Before } & \multicolumn{2}{|c|}{ During } & \multicolumn{2}{|c|}{$\begin{array}{l}\text { Forearm or } \\
\text { calf }\end{array}$} & \multicolumn{2}{|c|}{ Hand } & & \\
\hline & & & & & $\begin{array}{c}\text { Be- } \\
\text { fore }\end{array}$ & $\begin{array}{l}\text { Dur- } \\
\text { ing }\end{array}$ & $\begin{array}{c}\mathrm{Be}- \\
\text { fore }\end{array}$ & $\begin{array}{l}\text { Dur- } \\
\text { ing }\end{array}$ & $\begin{array}{c}\mathrm{Be}- \\
\text { fore }\end{array}$ & $\begin{array}{l}\text { Dur- } \\
\text { ing }\end{array}$ & $\begin{array}{c}\text { Con- } \\
\text { trol }\end{array}$ & $\underset{\text { sion }}{\text { Immer- }}$ & $\begin{array}{c}\text { Con- } \\
\text { trol }\end{array}$ & $\underset{\text { sion }}{\text { Immer- }}$ & $\begin{array}{l}\text { Be- } \\
\text { fore }\end{array}$ & $\begin{array}{l}\text { Dur- } \\
\text { ing }\end{array}$ & $\begin{array}{l}\text { Be- } \\
\text { fore }\end{array}$ & $\begin{array}{l}\text { Dur- } \\
\text { ing }\end{array}$ & $\begin{array}{l}\text { Be- } \\
\text { fore }\end{array}$ & $\begin{array}{l}\text { Dur- } \\
\text { ing }\end{array}$ \\
\hline & & & lbs. & $\begin{array}{l}c c . \\
\text { per } \\
\text { min- } \\
\text { ute }\end{array}$ & $m m$ & & $\begin{array}{l}\text { beats } \\
\text { min }\end{array}$ & $\begin{array}{l}\text { s per } \\
\text { oute }\end{array}$ & $\stackrel{m}{S a l}$ & mine & & & & & $\begin{array}{r}c c . \\
10 \\
\text { per }\end{array}$ & $\begin{array}{l}\text { per } \\
\text { of ce. } \\
\text { minute }\end{array}$ & $\begin{array}{c}c e \\
10 \\
\text { per }\end{array}$ & $\begin{array}{l}\text { c. per } \\
\text { oo ce. } \\
\text { minute }\end{array}$ & $\begin{array}{c}\text { Degr } \\
\text { centig }\end{array}$ & $\begin{array}{l}\text { grees. } \\
\text { igrade }\end{array}$ \\
\hline E. Z. & 20 & F. & 130 & 2 & $114 / 74$ & $138 / 100$ & 78 & 72 & 60 & 155 & $114 / 70$ & $130 / 100 \mid$ & $138 / 100$ & $144 / 116$ & 2.5 & $3.5-1.5$ & 13 & $19-3.9$ & 21.0 & 20.0 \\
\hline E. W. & 24 & F. & 125 & $\begin{array}{l}1 \\
2\end{array}$ & $\begin{array}{l}100 / 60 \\
100 / 60\end{array}$ & \begin{tabular}{l|}
$120 / 86$ \\
$160 / 104$ \\
\end{tabular} & 78 & 51 & $\begin{array}{l}60 \\
60\end{array}$ & $\begin{array}{l}100 \\
150\end{array}$ & $108 / 64$ & $110 / 60$ & $120 / 86$ & $130 / 84$ & 1.4 & $1.6-1.2$ & 18 & $18-2.5$ & $\begin{array}{l}33.2 \\
33.2\end{array}$ & $\begin{array}{l}31.0 \\
30.0\end{array}$ \\
\hline H. S. & 20 & F. & 115 & 3 & $116 / 64$ & $168 / 110$ & 72 & 60 & 95 & 160 & $120 / 60$ & $124 / 84$ & $164 / 110$ & $172 / 114$ & 1.8 & $1.8-1.7$ & 9.9 & $12.4-3.8$ & 31.5 & 30.0 \\
\hline N. P. & 43 & M. & 150 & $\begin{array}{l}3 \\
4\end{array}$ & $\begin{array}{l}124 / 74 \\
124 / 74\end{array}$ & \begin{tabular}{|l|}
$148 / 90$ \\
$170 / 104$
\end{tabular} & $\begin{array}{l}90 \\
72\end{array}$ & $\begin{array}{l}66 \\
72\end{array}$ & 60 & 160 & $124 / 74$ & $148 / 90$ & $148 / 90$ & $168 / 106$ & 2.5 & $3.6-2.5$ & 15 & $17-7.0$ & 19.5 & 19.5 \\
\hline A. $\mathbf{M}$. & 28 & M. & 145 & 2 & $108 / 60$ & $136 / 94$ & 78 & 66 & 135 & 150 & $106 / 64$ & $118 / 50$ & $130 / 90$ & $140 / 110$ & 3.5 & $2.5-3.3$ & 21 & $15-24$ & 17.5 & 17.5 \\
\hline V. M. & 45 & $\mathbf{M}$ & 150 & $\frac{1.5}{2}$ & $\begin{array}{l}114 / 70 \\
114 / 70\end{array}$ & $\begin{array}{l}144 / 94 \\
166 / 106\end{array}$ & 72 & 60 & & & & & & & & & 38 & $29-42$ & $\left|\begin{array}{r}34.0 \\
34.0\end{array}\right|$ & $\begin{array}{l}33.0 \\
31.0\end{array}$ \\
\hline D. $\mathbf{M}$. & 23 & M. & 161 & 4 & $124 / 68$ & $146 / 100$ & 84 & 66 & 80 & 160 & $126 / 74$ & $134 / 84$ & $146 / 100$ & $166 / 110$ & 2.8 & $7.0-3.5$ & 37 & $52-10$ & 31.0 & 27.5 \\
\hline A. $\mathbf{M}$. & 20 & F. & 120 & 5 & $104 / 64$ & $150 / 100$ & $\overline{80}$ & 73 & 65 & 170 & & & & & & & 25 & $23-1.9$ & $\mid 17.5$ & 17.0 \\
\hline W. L.t & 29 & M. & 167 & 5 & $98 / 64$ & $180 / 110$ & 66 & 54 & 70 & 195 & & & & & 2.2 & $3.4-1.7$ & 33 & 44-6.4 & 33.5 & 27.5 \\
\hline A. L. & 55 & M. & 180 & 4 & $118 / 78$ & $150 / 110$ & 90 & 84 & 45 & 110 & $118 / 78$ & $124 / 80$ & $150 / 110$ & $150 / 110$ & 1.7 & 2.5 & 26 & $28-14$ & 32.0 & 31.0 \\
\hline E. E. & 30 & F. & 109 & 2 & $124 / 74$ & $130 / 94$ & 108 & 72 & 100 & 150 & $120 / 72$ & $124 / 84$ & $130 / 94$ & $140 / 108$ & 2.7 & $4.2-3.4$ & 20 & $15-25$ & 19.5 & 19.0 \\
\hline M. B.* & 45 & F. & 135 & 3 & $124 / 70$ & $184 / 94$ & 66 & 48 & 80 & 120 & & & & & 2.0 & $6.3-2.0$ & $3.7 *$ & $3.9-3.0$ & 20.0 & 20.0 \\
\hline P. F. & 40 & $\mathbf{M}$. & 131 & 5 & $130 / 64$ & $208 / 110$ & & & 55 & 180 & & & & & & & & & & \\
\hline T. C. & 53 & $\mathbf{M}$. & 190 & 4 & $128 / 75$ & $185 / 108$ & 72 & 63 & 95 & 170 & & & & & & & & & & \\
\hline
\end{tabular}

* Circulation times: Before, 20 seconds; after, 23 seconds. Subject cool.

† Circulation times: Before, 18 seconds; after, 24 seconds.

ing the $x$-ray studies care was taken to prevent any movement of the subject in relation to the plates.

After all apparatus had been adjusted, at least half an hour was allowed to elapse before any Angiotonin was administered. Special precautions were taken to prevent the subject's knowing what was being given by substituting "blanks" of saline in cases of single injections or by changing from saline to Angiotonin, or vice versa, through a 3-way stop-cock during an intravenous infusion. Whenever an infusion apparatus was in place, as for measurements of venous pressure, single injections were made into the rubber tubing instead of directly into a vein. All venipunctures were rendered painless by antecedent novacainization.

The subjects were young adults without any evidence of cardiovascular disease (Tables I and II). They were studied usually in the recumbent position and were comfortably warmed by blankets and, if necessary, by electric heating pads. The warming was usually so regulated during the control period that vasodilatation occurred in the hands as shown by a temperature of $33^{\circ}$ to $35^{\circ} \mathrm{C}$. in the finger pads. The toes usually remained cool. This state represents one of moderate peripheral vasodilatation in which further vasodilatation would be apparent by an increase in temperature of the toes, or vasoconstriction by a decrease in temperature of the fingers. The cold test of Hines and Brown (28) was done by immersing the subject's hand in iced water $\left(4^{\circ} \mathrm{C}\right.$.) for 1 minute.

\section{RESULTS}

Angiotonin was administered intravenously by single injection 150 times in 40 subjects (Table I) and by continuous infusion 14 times in 14 subjects (Table II). Some 15 to 30 seconds after an injection of Angiotonin, arterial pressure began to rise, and in about 2 minutes reached its peak, the height of which, in a given subject, was roughly proportional to the amount of Angiotonin injected. The systolic pressure rose somewhat more than the diastolic, resulting in an increase in pulse pressure (Figures $1,2,3$ ). This increase in pulse pressure was always apparent in the records obtained with the Hamilton manometer (Figure 1). In some cases when the auscultatory 


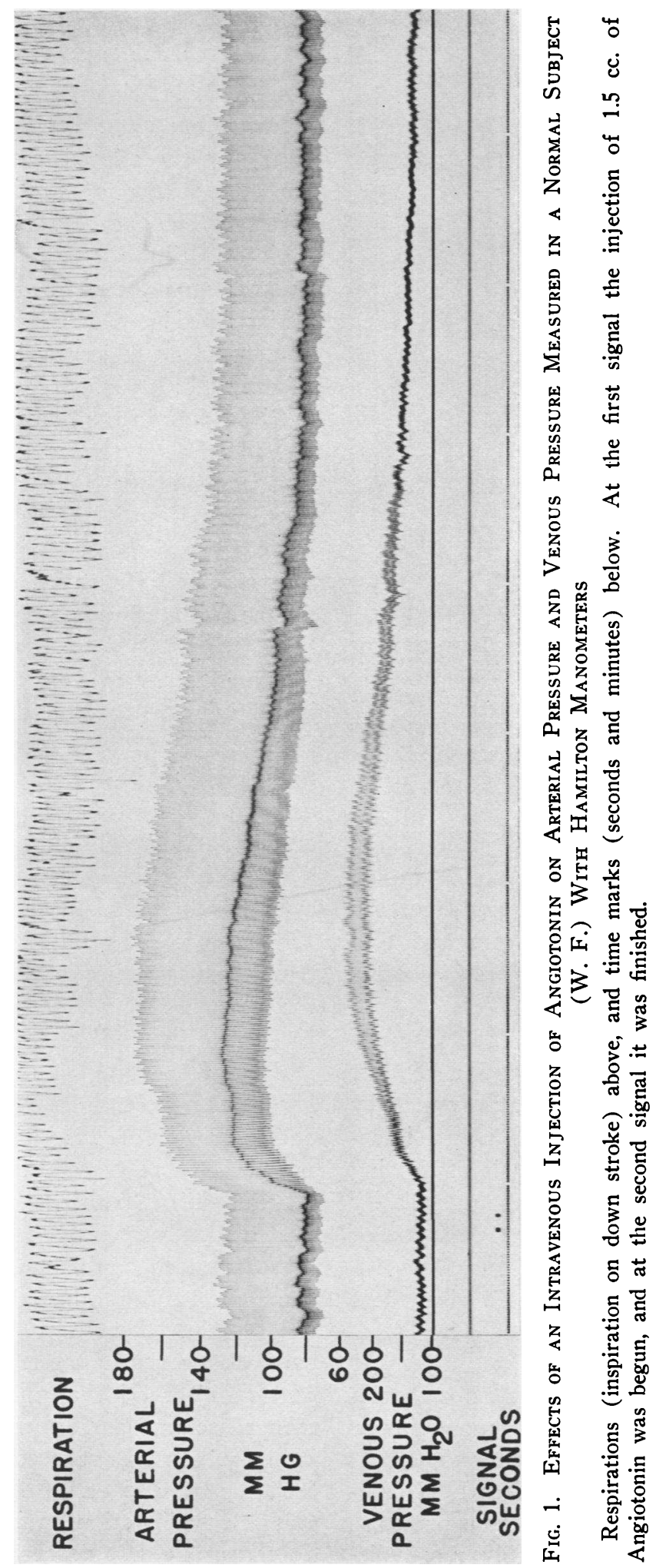




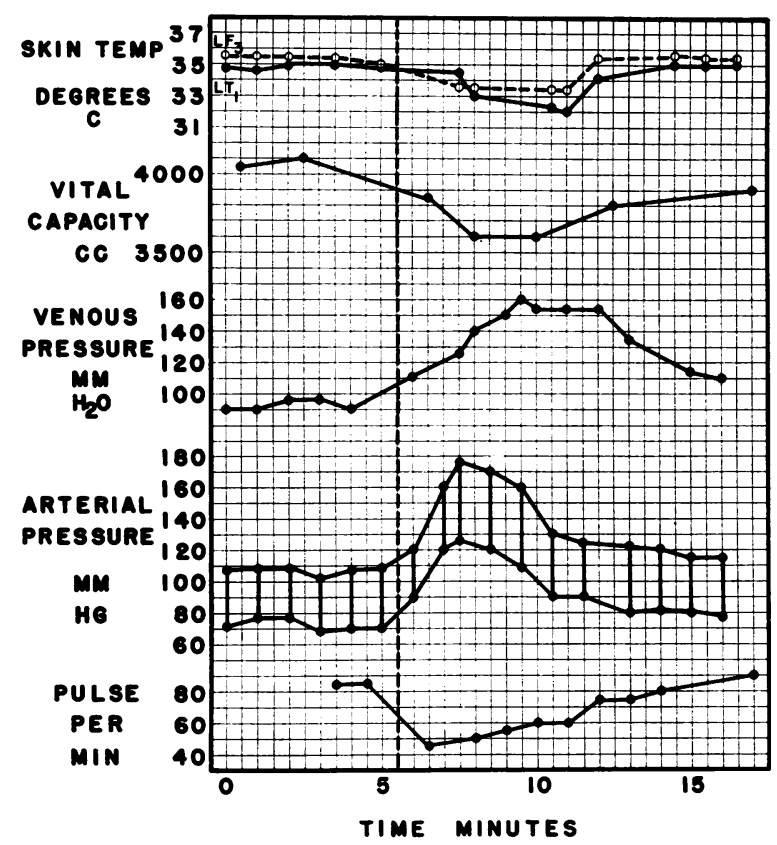

Fig. 2. Effects of an Intravenous Injection of Angiotonin on Pulse Rate, Arterial Pressure, Venous Pressure, Vital Capacity and Skin Temperature of the Left GREat Toe ( $\mathrm{L} \mathrm{T}_{1}$ ) and of the Left Third Finger ( $\mathrm{L} \mathrm{F}_{3}$ ) of a Normal Subject (B. Z.)

At $5 \frac{1}{2}$ minutes (interrupted vertical line) $2 \mathrm{cc}$. of Angiotonin were administered.

method was used, it was difficult to determine accurately the associated systolic and diastolic pressures, because of the bradycardia and also because of a muffling of the first sounds coming past the cuff.

There was bradycardia (Tables I, II, Figures $1,2,3)$ with pulse rates often as low as 55 per minute. This bradycardia could be prevented by atropine. After atropinization (2 $\mathrm{mgm}$. intravenously) Angiotonin did produce slight slowing of the pulse initially, but this was immediately followed by an acceleration of the pulse to or above its control level (Table I, Figure 4). Incidentally, the hypertensive effect of a given dose of Angiotonin was greatly enhanced after atropinization.

With the rise of arterial pressure after Angiotonin, venous pressure also rose, but more slowly, reaching its peak about 1 minute after the maximum rise in arterial pressure (Tables I, II, Figures $1,2,3$ ). During the rise of venous pressure, the neck veins often became visibly more distended.
Respiration usually quickened slightly, but there was never any subjective sensation of dyspnea. However, the vital capacity decreased significantly (Tables I, II, Figures 2, 3).

Rectal temperature was never significantly affected by the administration of Angiotonin but the temperature of the skin usually decreased slightly (Tables I, II, Figures 2, 3). In many subjects definite pallor was apparent. Angiotonin when injected intradermally $(0.1 \mathrm{cc}$.) in 5 subjects produced definite local blanching, but not so marked or widespread as that produced by a solution $(1: 1000)$ of epinephrine $(0.1 \mathrm{cc}$.).

Blood flow in the limbs usually decreased moderately, but not always (Tables I, II). Characteristically, in the limbs the response was phasic, consisting of an initial increase in blood flow, followed by a decrease and finally a return to the control level (Figure 5). The changes in volume of the limbs always reflected the alterations in blood flow.

Some interest was attached to the nature of the initial increase in blood flow which occurred in the limbs after an intravenous injection of Angiotonin, since evidence was obtained that the local action of Angiotonin is vasoconstrictor: Minute amounts (up to $0.1 \mathrm{cc}$.) of Angiotonin injected directly into the femoral artery of 4 subjects caused only vasoconstriction locally in the calf (Figure 6). The initial vasodilatation after intravenous injection appeared simultaneously in the forearm and calf with the first rise of arterial pressure (Figure 5) and often before the expected arrival of the Angiotonin in the part, as calculated from the circulation time. The appearance and amplitude of this increase in blood flow were not directly related to the size of the dose of Angiotonin or to the height to which the arterial pressure subsequently rose. These facts suggested that this initial vasodilatation was due to some mechanism other than the local action of Angiotonin. That it probably was the result of sympathetic vasomotor activity was demonstrated in a subject with a unilateral (right) cervical sympathectomy performed 9 years previously for epilepsy. In this subject the intravenous administration of $0.15 \mathrm{cc}$. of Angiotonin produced the initial vasodilatation in the normally innervated forearm, but only vasoconstriction in the sympatectomized forearm (Figure 7). 


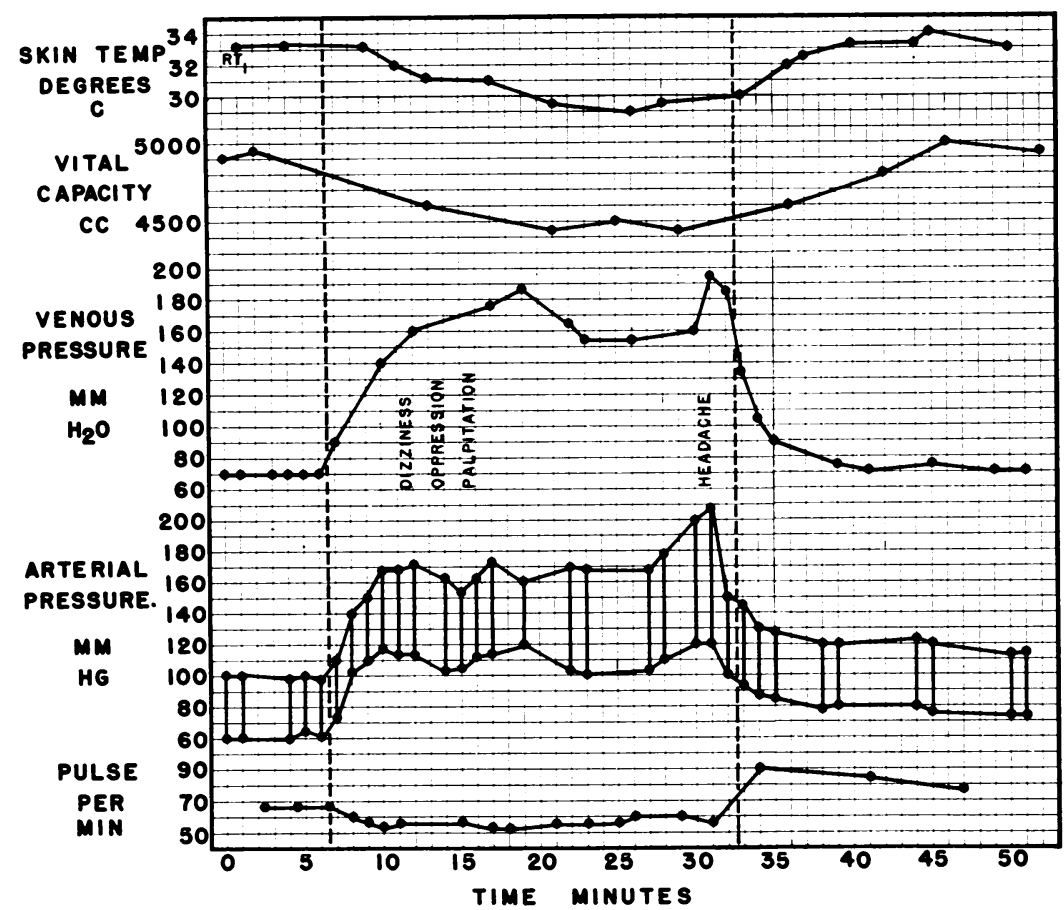

Fig. 3. Effects of an Intratexols Infesion of Axgiotonis on Pllase Rate, Arterial Presslie, Vexols Presslre, Vital Capacity, axd Skix Temperatlre of the Right Great Toe of a Normal Stbject (IV. L.)

At $61 / 2$ minutes (first interrupted vertical line) the infusion of a 10 per cent solution of Angiotonin was begun, at a rate of $5 \mathrm{cc}$. per minute. Symptoms noted by the subject are recorded. At 321/2 minutes (second interrupted vertical line) the infusion of Angiotonin was ended.

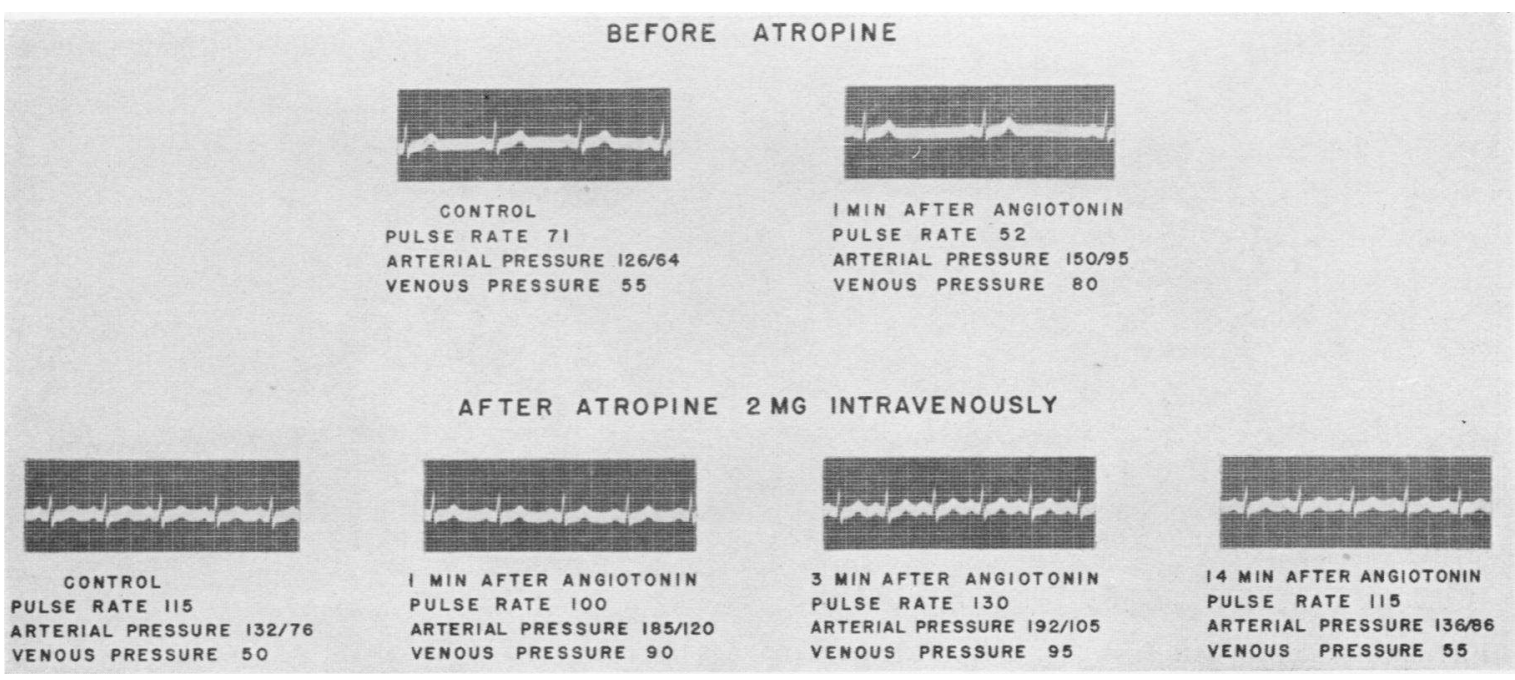

Fig. 4. Effects of ax Ixtravexols Ixjection of Axgiotonin (0.5 cc.) on the Electrocardogram (Lead 1) of a Normal Subject (P. F.), Bffore axd After Atropinization (2 igg. Atropine Ixtravexously) 
Spinal fluid pressur measured either in the lumbar or cisternal space of 5 subjects was not significantly altered by injections of Angiotonin which caused marked rises of arterial pressure
(Table I). A small rise ( $20 \mathrm{~mm}$. H.O ) in spinal fluid pressure usually occurred, but this amount of change, or more. could be produced by questioning the subject, or by his changing his re-

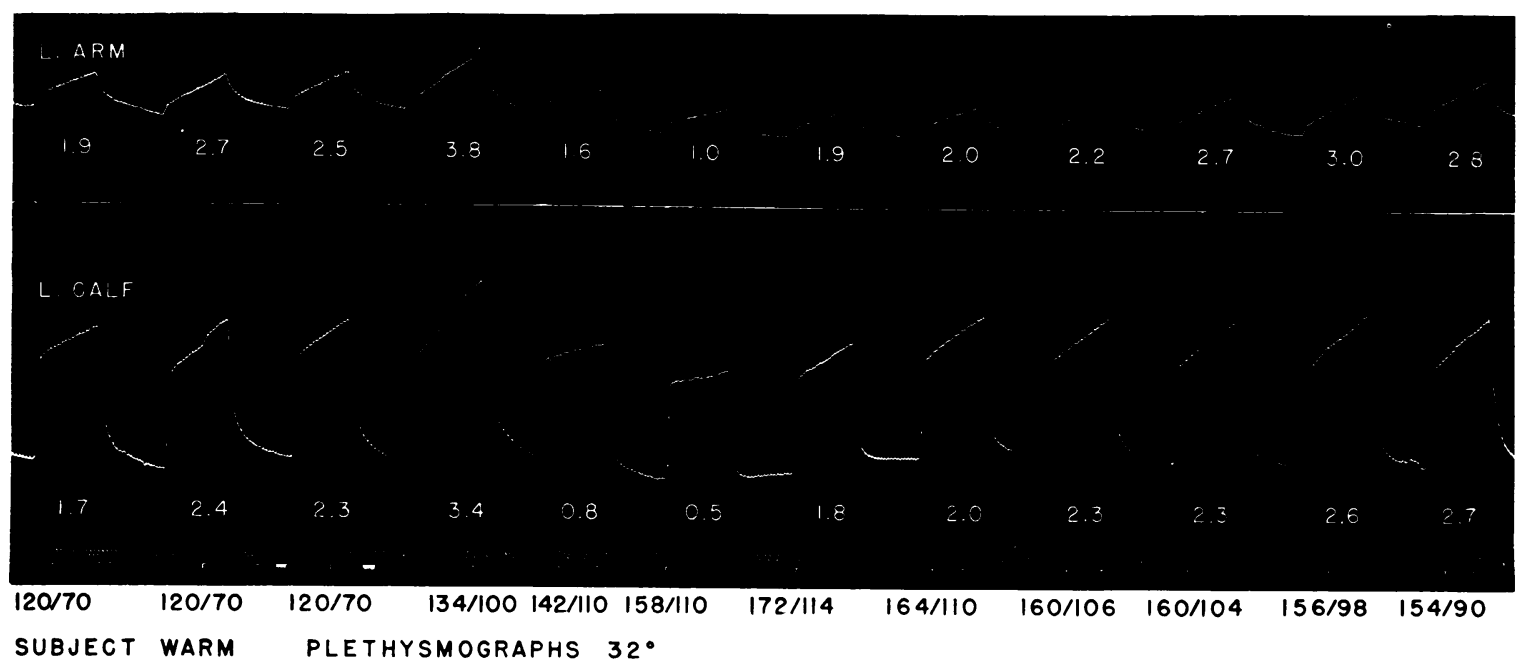

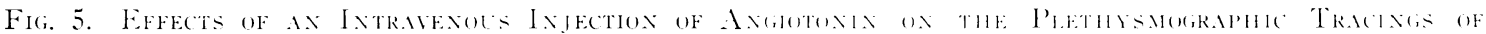

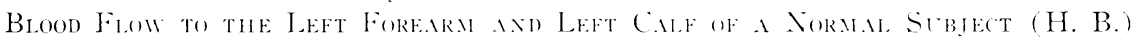

The first sharp rise of each tracing of bloxd flow (especially marked in the calf) is due to the displacement of tissue into the plethysmograph by inflation of the proximal cuff. The true blow flow is indicated by the steepness of the straight portion of the curve following the initial sharp rise. The figures under each tracing of blood flow give its calculated value in ec. per 100 ec. per minute. Time: seconds. Signals: single, for measurement of arterial pressure, given below in $\mathrm{mm}$. He; multiple. for beginning and end uf an intravenous injection of 2 cc. of Angiotonin.

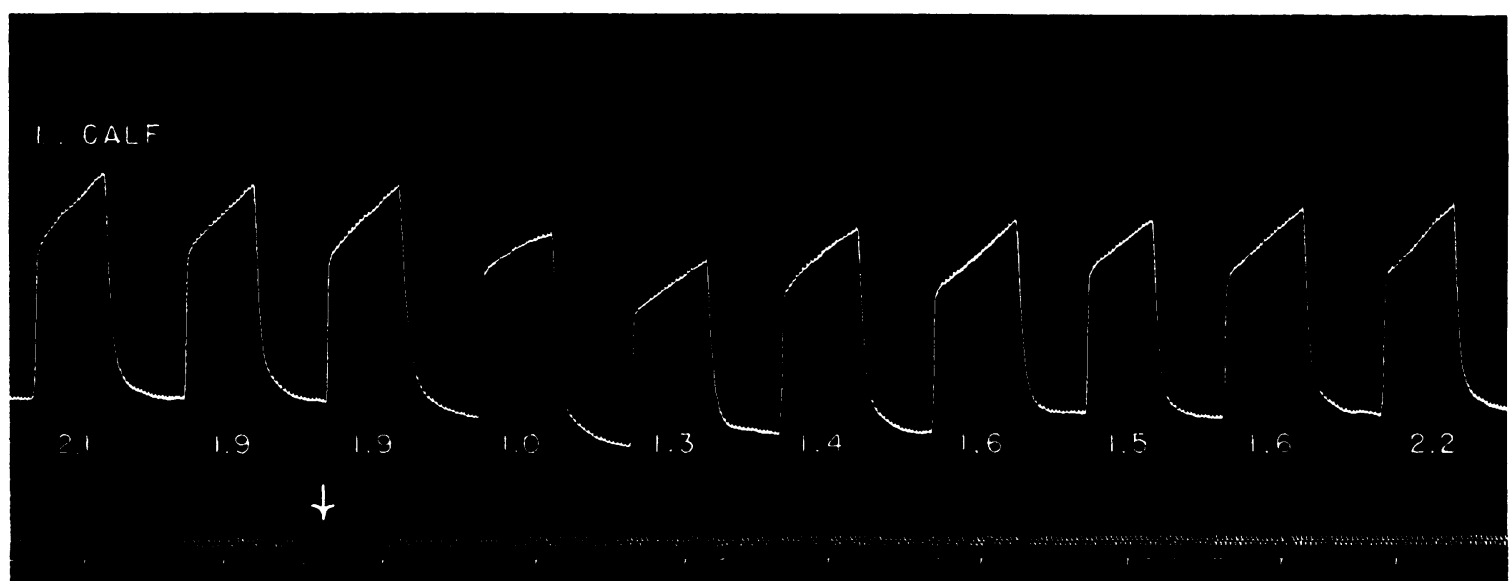

\section{$\begin{array}{llllllllll}112 / 74 & 110 / 70 & 114 / 74 & 110 / 74 & 112 / 74 & 114 / 72 & 114 / 70 & 114 / 70 & 110 / 70 & 114 / 72\end{array}$ SUBJECT WARM PLETHYSMOGRAPHS $32^{\circ}$}

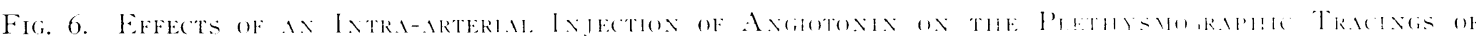

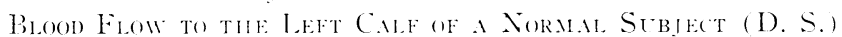

The figures under each tracing of blood flow give its calculated alue in ce. per lou ce. per minute. Time: seconds. Signals: short, for measurement of arterial pressure given below in mm. Hg: long (arrow), for an injection of $0.4 \mathrm{cc}$. 10 per cent Angiotonin into the leit femoral artery. 


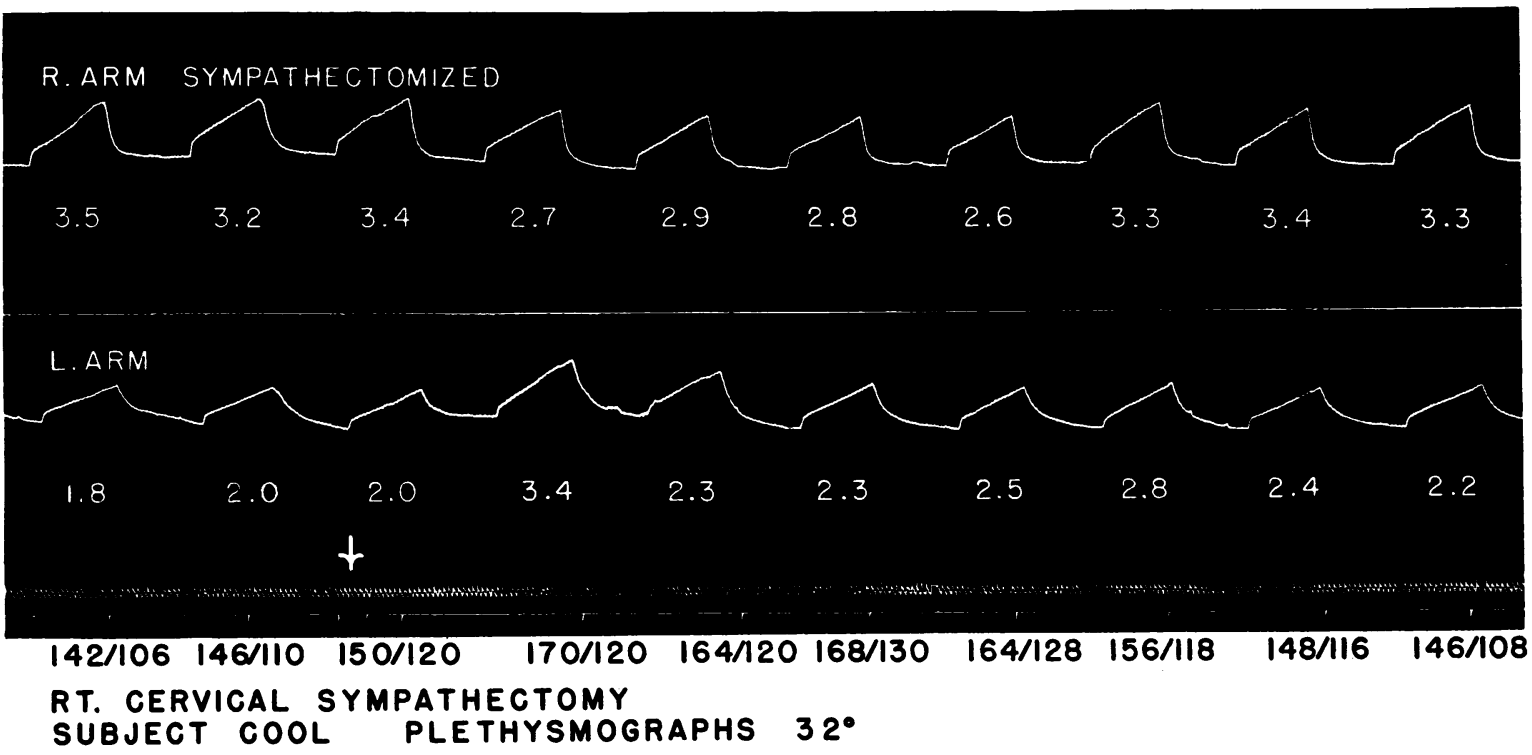

Fig. 7. Effects of an Intravexols Ixjection of Angiotonix on the Plethysiographic Tracings of Blood Flow to the Left Forearm and Right Forearm of a Slbject (L. R.) Who Had Sustained a Right Cervical Sympathectony 9 Years Previolsly for Epilepsy

The figures under each tracing of blood flow give its calculated value in cc. per 100 cc. per minute. Time: seconds. Signals: short, for measurement of arterial pressure, given below in $\mathrm{mm}$. $\mathrm{Hg}$; long (arrow), for an intravenous injection of $0.15 \mathrm{cc}$. Angiotonin.

spiratory rate slightly. It was therefore not considered significant.

No differences were found in the action of Angiotonin given by single injection and by continuous intravenous infusion (Table II) except for the duration of the effects which could be prolonged apparently unchanged for periods up to three quarters of an hour (Figures 3, 8, 9). No experiments were carried on longer than this. mainly because of the scarcity of the Angiotonin. When the rate of an infusion was increased, there was a further rise in arterial pressure (Table II, Figure 8 ). Thus by varying the rate of administration, any desired level of arterial pressure could be maintained. The other circulatory effects produced by Angiotonin also continued at stable levels as long as a constant infusion was given.

During the hypertension due to Angiotonin mild symptoms of dizziness, substernal oppression, palpitation, nausea or headache were occasionally noted. None of these was severe, except in one instance cluring an infusion when a headache accompanied a sharp further rise in arterial pressure (Figure 3). This sharp increase was

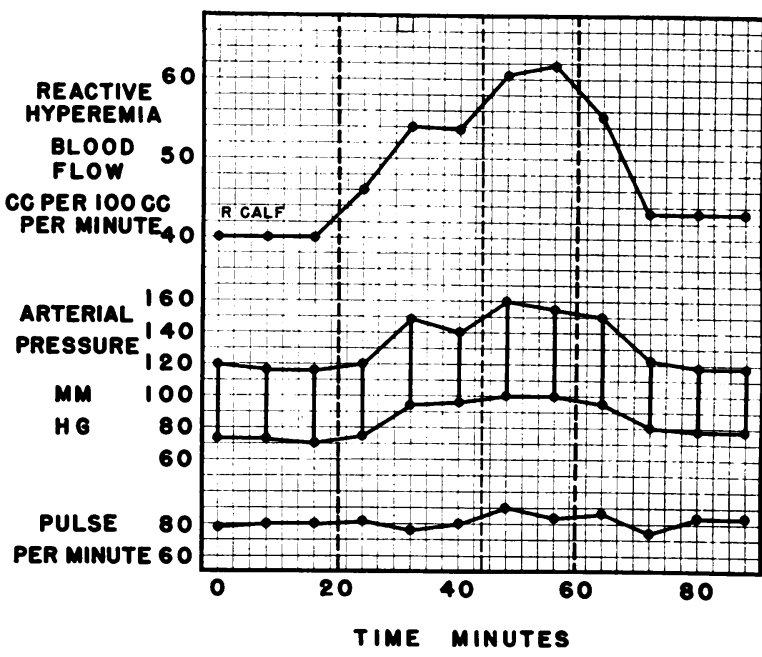

Fig. 8. Effects of an Intravenous Infusion of Angiotonin on the Pulse Rate, Arterial Pressurf axd Reactive-Hyperenia Bloon Flow in the Right Calf of a Normal Subject (V. M.)

At 20 minutes (first interrupted vertical line) an intravenous infusion of 10 per cent Angiotonin was started at a rate of $1.5 \mathrm{cc}$. per minute. At 44 minutes (second interrupted vertical line) the rate of infusion was increased to $2 \mathrm{cc}$. per minute. At 60 minutes (third interrupted vertical line) the infusion of Angiotonin was ended. 
thought to be due to the fact that just previously the subject had made a particularly strenuous expiratory effort for the test of vital capacity, probably holding some of the solution back in the vein. With the subsequent deep inspiration this was quickly drawn into the general circulation, producing the sudden further rise. At any rate, the infusion was stopped, and the headache and hypertension quickly subsided.

During an infusion of Angiotonin the blood flow in the limbs remained under the control of the sympathetic nervous system. Vasoconstrictions and vasodilatations known to be mediated by the sympathetic nervous system $(24,29)$ took place as before in response to stimuli. For example, vasodilatation in the feet, in response to

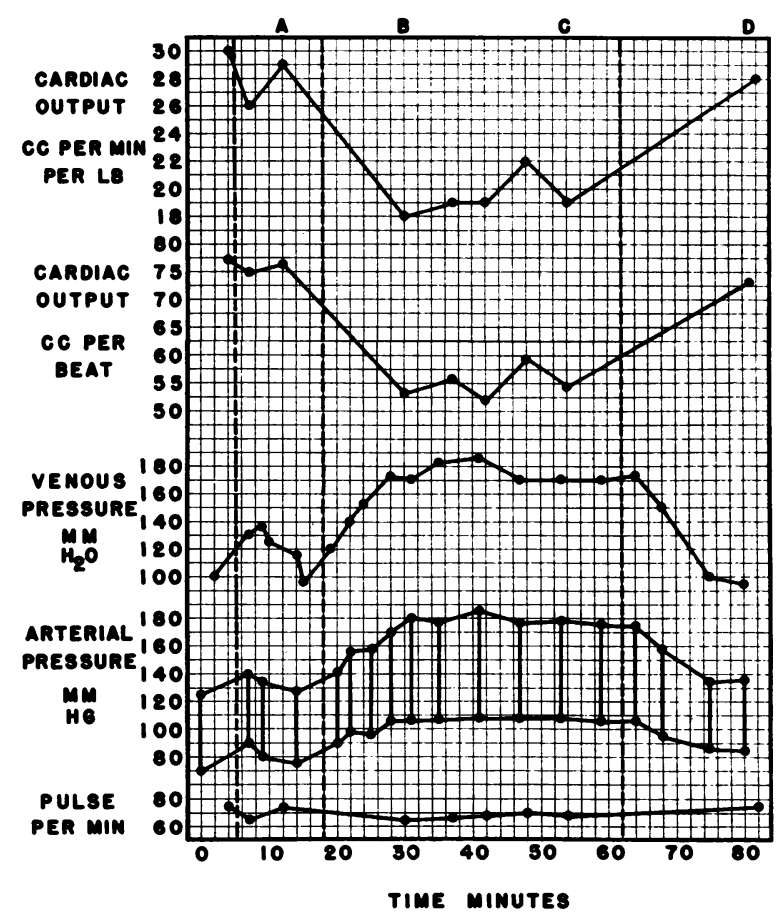

Fig. 9. Effects of Angiotonin on the Pulse Rate, Arterial Pressure, Venous Pressure and Cardiac Output (Per Beat and Per Minute) of a Patient (L. C.) With Eczema

At 5 minutes (first interrupted vertical line) a single intravenous injection of $1.5 \mathrm{cc}$. Angiotonin was given. At 18 minutes (second interrupted vertical line) an intravenous infusion of 10 per cent Angiotonin was started at a rate of $4 \mathrm{cc}$. per minute. At 62 minutes (third interrupted vertical line) the infusion of Angiotonin was ended. The letters at the top of the chart refer to representative ballistocardiographic tracings shown in Figure 10 .
TABLE III

Reactive-hyperemia blood flow

\begin{tabular}{l|l|l|c|c|c}
\hline \hline \multirow{2}{*}{ Name } & $\begin{array}{l}\text { Amount of } \\
\text { angiotonin }\end{array}$ & \multicolumn{2}{|c|}{ Arterial pressure } & \multicolumn{2}{|c}{ Blood flow } \\
\cline { 3 - 5 } & Control & After & Control & After \\
\hline
\end{tabular}

SINGLE INJECTIONS

\begin{tabular}{l|l|l|l|c|c}
\hline & $c c$. & $m m . H g$ & $m m . H g$ & $\begin{array}{c}c c . \text { per } \\
100 \text { cc. } \\
\text { per minute } \\
32\end{array}$ & $\begin{array}{c}c c \text { per } \\
100 \text { cc. } \\
\text { per minute } \\
44\end{array}$ \\
\hline E. T. & 1.0 & $120 / 70$ & $146 / 90$ & 32 & 48 \\
\hline D. M. A. & 1.0 & $120 / 64$ & $144 / 90$ & 32 & 48 \\
\hline H. B. & 1.0 & $114 / 74$ & $182 / 110$ & 18 & 33 \\
\hline & 0.1 & $118 / 70$ & $124 / 78$ & 28 & 32 \\
& $0.1^{*}$ & $118 / 70^{*}$ & $124 / 78^{*}$ & $34^{*}$ & $34^{*}$ \\
& 1.0 & $120 / 74$ & $138 / 100$ & 27 & 41 \\
& $1.0^{*}$ & $120 / 74^{*}$ & $138 / 100^{*}$ & $25^{*}$ & $45^{*}$ \\
& 2.0 & $114 / 70$ & $150 / 114$ & 24 & 43 \\
& $2.0^{*}$ & $114 / 70^{*}$ & $150 / 114^{*}$ & $28^{*}$ & $51^{*}$ \\
\hline
\end{tabular}

INFUSIONS

\begin{tabular}{l|c|c|c|c|c}
\hline E. E. & $\begin{array}{c}c c . \text { per } \\
\text { minute } \\
2\end{array}$ & $114 / 68$ & $140 / 100$ & 20 & 28 \\
\hline A. L. & 4 & $124 / 82$ & $156 / 100$ & 21 & 28 \\
\hline A. M. & 4 & $108 / 68$ & $136 / 98$ & 25 & 31 \\
\hline V. M. & 1.5 & $114 / 70$ & $\begin{array}{l}148 / 94 \\
160 / 100\end{array}$ & $\begin{array}{l}31 \\
31\end{array}$ & $\begin{array}{l}54 \\
61\end{array}$ \\
\hline A. M. & 5 & $108 / 64$ & $130 / 84$ & 13 & 21 \\
\hline N. P. & 4 & $120 / 74$ & $166 / 98$ & 18 & 25 \\
\hline H. S. & 3 & $120 / 60$ & $148 / 100$ & 23 & 28 \\
\hline E. Z. & 2 & $116 / 64$ & $146 / 104$ & 16 & 29 \\
\hline
\end{tabular}

* = Left arm. Other flows = Left leg.

strong warming of the body, if begun during the control period, continued (after a slight pause) when Angiotonin was administered. Likewise, vasoconstriction in response to the cold test of Hines and Brown took place during an infusion of Angiotonin, as before. It is of considerable interest that the pressor response to the cold test of Hines and Brown was not significantly altered in 8 normal subjects during the hypertension produced by an infusion of Angiotonin (Table II).

The reactive-hyperemia blood flow, in the forearm or calf (during full local vasodilatation produced by a 5-minute period of arterial occlusion), increased with the rise of arterial pressure due to Angiotonin, and decreased when the arterial hy- 
TABLE IV

Cardiac output

\begin{tabular}{|c|c|c|c|c|c|c|c|c|c|c|c|c|c|c|c|c|c|}
\hline \multirow[b]{2}{*}{ 孞 } & \multirow[b]{2}{*}{$\underset{4}{\infty}$} & \multirow[b]{2}{*}{ ஸั } & \multirow[b]{2}{*}{ 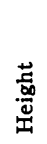 } & \multirow[b]{2}{*}{ 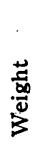 } & \multirow{2}{*}{ 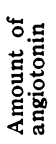 } & \multicolumn{3}{|c|}{ Arterial pressure } & \multicolumn{3}{|c|}{ Pulse rate } & \multicolumn{3}{|c|}{ Cardiac output } & \multicolumn{3}{|c|}{ Cardiac output } \\
\hline & & & & & & $\begin{array}{l}\text { Con- } \\
\text { trol }\end{array}$ & $\begin{array}{c}\text { Angio- } \\
\text { tonin }\end{array}$ & $\begin{array}{c}\text { Re- } \\
\text { covery }\end{array}$ & $\begin{array}{l}\text { Con- } \\
\text { trol }\end{array}$ & $\begin{array}{c}\text { Angio- } \\
\text { tonin }\end{array}$ & $\begin{array}{l}\text { Re- } \\
\text { cov- } \\
\text { ery }\end{array}$ & $\begin{array}{l}\text { Con- } \\
\text { trol }\end{array}$ & $\begin{array}{c}\text { Angio- } \\
\text { tonin }\end{array}$ & $\begin{array}{l}\text { Re- } \\
\text { cov- } \\
\text { ery }\end{array}$ & $\begin{array}{l}\text { Con- } \\
\text { trol }\end{array}$ & $\underset{\text { tonin }}{\text { Angio- }}$ & $\begin{array}{l}\text { Re- } \\
\text { cov- } \\
\text { ery }\end{array}$ \\
\hline
\end{tabular}

HORIZONTAL POSITION

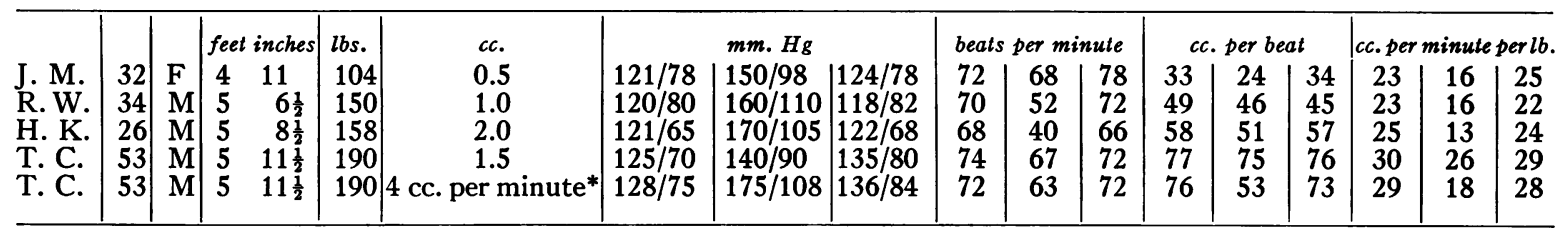

VERTICAL POSITION

\begin{tabular}{|c|c|c|c|c|c|c|c|c|c|c|c|c|c|c|c|c|c|c|}
\hline $\begin{array}{l}\text { R. W. } \\
\text { H. K. }\end{array}$ & $\begin{array}{l}34 \\
26\end{array}$ & $\begin{array}{l}\mathbf{M} \\
\mathbf{M}\end{array}$ & $\begin{array}{l}5 \\
5\end{array}$ & $\begin{array}{l}6 \frac{1}{2} \\
8 \frac{1}{2}\end{array}$ & $\begin{array}{l}150 \\
158\end{array}$ & $\begin{array}{l}1.0 \\
2.0\end{array}$ & $\begin{array}{l}120 / 100 \\
116 / 70\end{array}$ & $\begin{array}{l}148 / 120 \\
145 / 90\end{array}$ & $\begin{array}{l}125 / 100 \\
115 / 68\end{array}$ & $\begin{array}{l}82 \\
85\end{array}$ & $\begin{array}{l}68 \\
60\end{array}$ & $\begin{array}{l}76 \\
80\end{array}$ & $\begin{array}{l}43 \\
42\end{array}$ & $\begin{array}{l}40 \\
35\end{array}$ & $\begin{array}{l}43 \\
39\end{array}$ & $\begin{array}{l}23 \\
23\end{array}$ & $\begin{array}{l}18 \\
13\end{array}$ & $\begin{array}{l}22 \\
20\end{array}$ \\
\hline
\end{tabular}

* Infusion of 10 per cent solution of angiotonin.

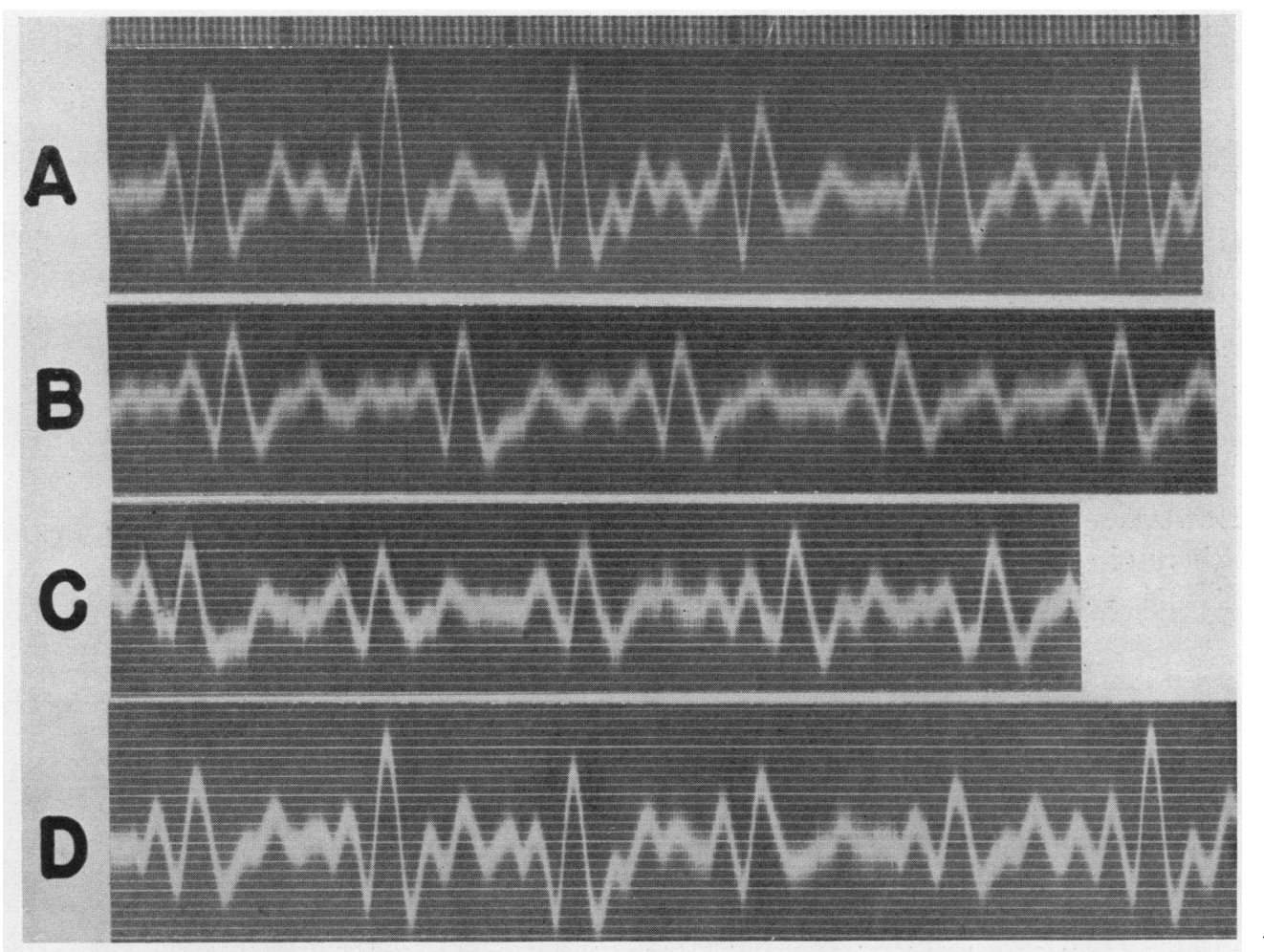

Fig. 10. Representative Ballistocardiographic Tracings Obtained in the Experiment SHOWN IN Figure 9

The letters correspond to the times indicated at the top of Figure 9. 

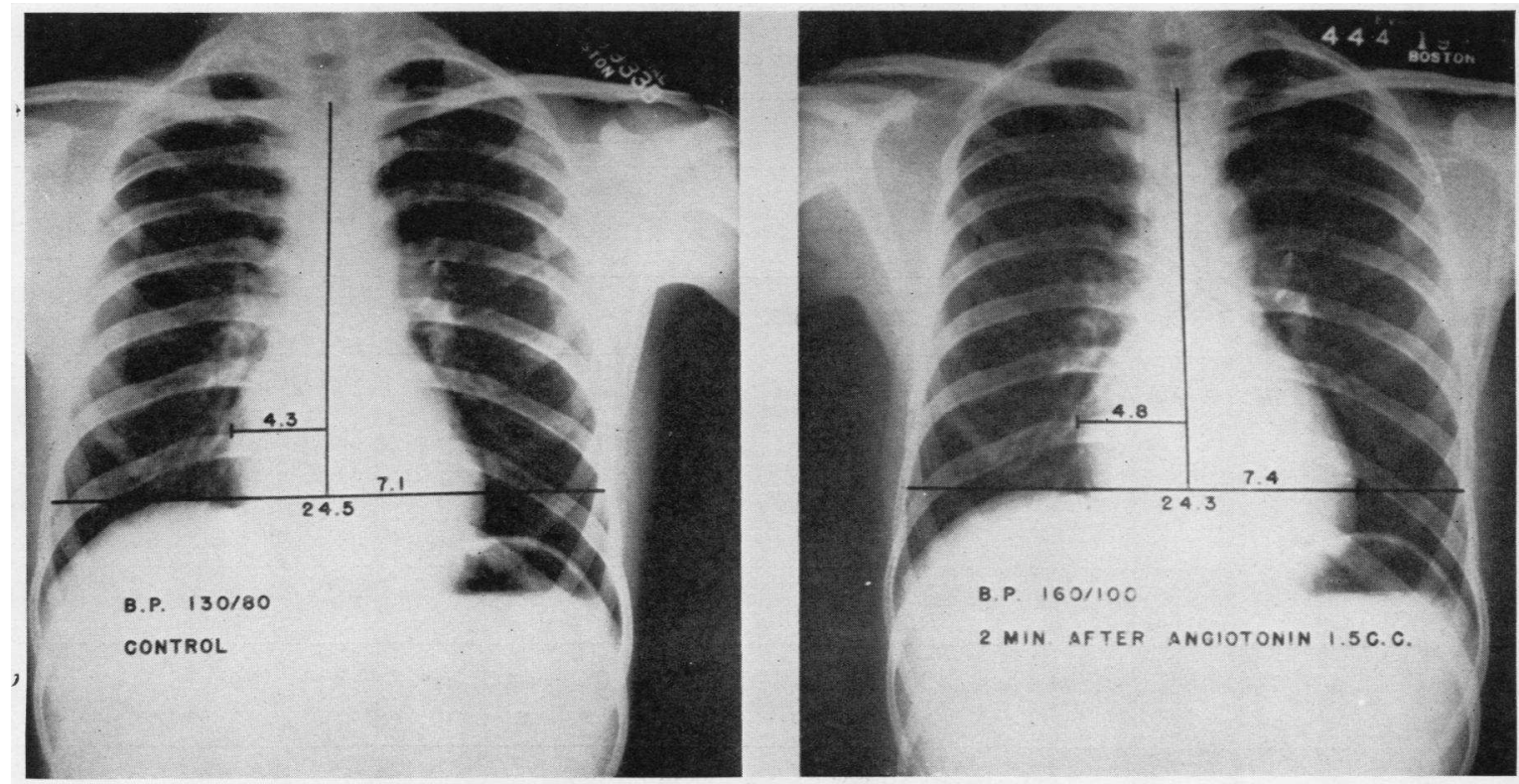

Fig. 11. Effects of an Intravenous Injection of Angiotonin (1.5 cc.) on the Teleoroentgenograms of a Normal Male (W. F.)

Cardiac measurements are given in $\mathrm{cm}$. Arterial pressures recorded below in $\mathrm{mm}$. $\mathrm{Hg}$ were taken immediately before the teleoroentgenograms.

pertension subsided after the infusion of Angiotonin was stopped (Table III, Figure 8).

The cardiac output (blood flow to the entire body) measured ballistocardiographically in the supine and upright positions decreased after Angiotonin, both when calculated as cc. per minute per pound, and as cc. per beat ${ }^{3}$ (Table IV). In one subject (Figure 9) after a single injection of Angiotonin, with a moderate rise of arterial and venous pressures, the change in output per beat was negligible, probably because of the bradycardia. However, during an infusion of Angiotonin, which resulted in a prolonged marked rise of arterial and venous pressures, there was a profound decrease in the cardiac output per beat as well as per minute (Figures 9, 10).

The arm-to-carotid sinus circulation time usually increased, often only slightly, but occasionally considerably (Tables I, II).

The electrocardiograms showed no significant changes other than the bradycardia (Figure 4).

$X$-ray examinations of the heart showed in 6 of 8 subjects a small but definite increase in the

${ }^{3}$ So calculated for the sake of comparison. The absolute values may, with the newer knowledge of the ballistocardiogram, prove slightly inaccurate quantitatively. cardiac size (Table V, Figure 11). Kymograms usually showed a slight decrease in the amplitude of the cardiac pulsations. In some subjects, in addition to the increase in the cardiac shadow, there was also an increase in the pulmonary markings.

The effects of Angiotonin administered intravenously subsided gradually in 4 to 10 minutes after the cessation of the administration, whether by continuous infusion or by single injection.

TABLE V

Teleoroentgenograms of heart

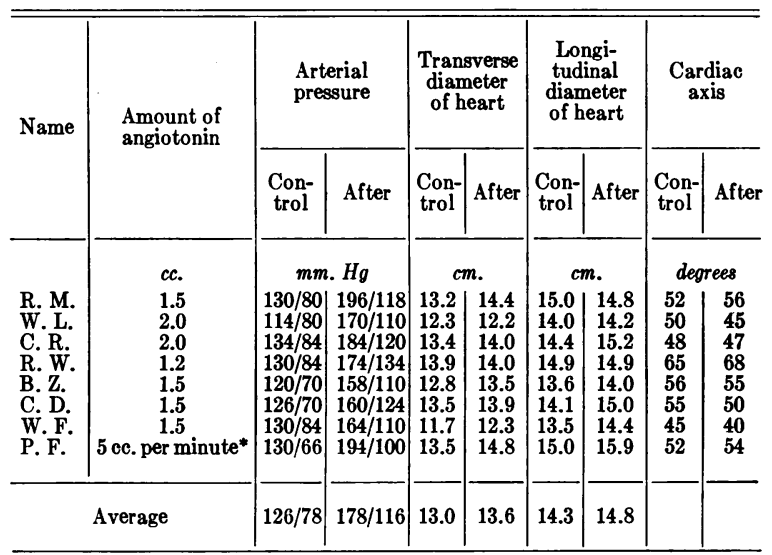

* Infusion of 10 per cent solution of angiotonin. 


\section{DISCUSSION}

The most interesting aspect of the arterial hypertension produced by Angiotonin is the associated evidence of " myocardial failure" occurring in otherwise normal individuals. An increase in venous pressure, decrease in vital capacity, increase in cardiac size, decrease in cardiac output and increase in circulation time, all important signs of heart failure, were frequently found. The mode by which Angiotonin could produce heart failure is difficult to explain, unless it exerts a direct "toxic" action on the myocardium. The experimental evidence in animals is against this explanation. On the contrary, Angiotonin seems to exert a stimulating or "tonic" effect on the myocardium (isolated heart), increasing its output and efficiency $(29,30)$.

It would appear that in man Angiotonin produces marked and generalized peripheral vasoconstriction, since it causes not only a rise in arterial pressure but also a decrease in cardiac output. The effects on cardiac output here reported are in essential agreement with those of Bradley and Parker (32). Likewise, the blood flow in every area in which measurements have been made, including the renal $(33,34)$, has been found to decrease after Angiotonin, at least initially. The peripheral vasoconstriction must be primarily on the arterial (arteriolar) side of the circulation since the rise of arterial pressure precedes the increase in venous pressure and the other signs of " myocardial failure."

Except for the rise in venous pressure and the decrease in cardiac output, the circulatory effects of Angiotonin, though definite when compared with the control measurements of the same subject, usually are not so great as to be clearly abnormal. Hence the increase in venous pressure and decrease in cardiac output can be said to be the outstanding characteristics of the Angiotonin hypertension.

It is difficult to judge whether naturally occurring hypertension is similar to the hypertension due to Angiotonin. However, one can state that, as commonly accepted, essential hypertension is not entirely similar to the hypertension of Angiotonin. The chief difference is the absence of a significant elevation of venous pressure such as was observed after Angiotonin. On the other hand, as Starr has pointed out, a decrease in cardiac output, measured ballistocardiographically, is found in a considerable number of patients with essential hypertension (34). Furthermore, the amount of the decrease is about the same as that produced by Angiotonin (35). A possible explanation for the absence of the increased venous pressure and the other signs of "myocardial failure" in established cases of essential hypertension is that such signs may have been present initially, only to disappear after sufficient time had elapsed for the adjustments of "compensation" to take place.

One form of naturally occurring hypertension, namely that associated with acute hemorrhagic nephritis, does seem to be similar to the hypertension of Angiotonin. Both are characterized by an elevation of venous pressure and by $\mathbf{x}$-ray evidence of increases in cardiac size and pulmonary congestion (36). These similarities may be apparent not only because of the sudden onset and acute nature of the two types, but also because of the availability of control or recovery measurements in the same individuals for comparison.

The blood flow in the limbs after the administration of Angiotonin tends to decrease, but remains under the control of the sympathetic nervous system. The resting blood flow, after an initial phasic variation, may be slightly, or even considerably, below the control level, but sympathetic vasodilatation and vasoconstriction can occur as before in response to appropriate stimuli. In this respect the hypertension due to Angiotonin is compatible with essential hypertension. The variable amount of the increase in circulation time in different individuals after Angiotonin could be explained entirely on the variable amount of associated decrease in the peripheral blood flow (37).

That Angiotonin produces local vasoconstriction is established not only from the evidence already cited, but also by the observations on its vasoconstrictor effects when injected intradermally or intra-arterially. But it is important that the peripheral vasoconstriction caused by Angiotonin can be released by physiologic procedures producing vasodilatation. Thus the reactive-hyperemia blood flows obtained during full local 
vasodilatation after a 5-minute period of arterial occlusion increased along with the arterial pressure. This demonstrates that there is no danger of an inadequate blood flow with tissue anoxia in the extremities during the action of Angiotonin. On the contrary, because of the higher arterial pressure, the blood flow, if needed, can actually be greater than normal.

These observations on the reactive-hyperemia blood flow during the hypertension produced by Angiotonin are similar to those obtained during other pressor procedures (38). They emphasize the direct relationship which exists in a given individual between arterial pressure and blood flow in the limbs under controlled vasodilatation. But again, because of the wide scattering of the values for blood flow obtained in different individuals, whether normal or hypertensive, such measurements are of questionable value in estimating the degree and nature of the peripheral resistance to blood flow in a random subject or in two groups of individuals. It can be stated, however, that the reactive-hyperemia blood flows obtained during the hypertension due to Angiotonin are comparable with those obtained in young individuals with naturally occurring hypertension. Therefore, they are consistent with the conclusion that the increased peripheral resistance to blood flow in such hypertensive patients also can be released by similar physiologic vasodilatation.

The prevention of bradycardia after Angiotonin by atropine would indicate that the cardiac slowing is probably vagal in origin. Furthermore, the fact that the hypertensive effect of a given dose of Angiotonin is enhanced after atropine shows that the bradycardia is an important moderator mechanism. Probably another such moderator mechanism, though less effective, is the initial sympathetic vasodilatation in the limbs after Angiotonin.

It was surprising to find that no significant rise in spinal fluid pressure occurred after Angiotonin, in spite of considerable increases of arterial and venous pressures. This was interpreted as indicating that after Angiotonin a marked vasoconstriction occurs in the small vessels of the cerebrospinal contents, with a probable decrease in blood flow. This change was thought to be analogous to the decrease in volume and blood flow which may occur in the limbs after Angiotonin along with a rise of arterial and venous pressures.

The finding of no significant difference in the pressor response to the cold test of Hines and Brown in the same subject when normal, and when hypertensive from Angiotonin, is of considerable interest. It casts doubt upon the usual explanation of why there should be a hyper-reactor response in hypertensive, or potentially hypertensive, individuals. This explanation postulates a greater amount of sympathetic vasoconstrictor " reserve" in such persons, due to a state of relative sympathetic vasodilatation which, in turn, is a moderator response to the presence of a circulating pressor substance. This greater reserve is called into play by a strong vasoconstrictor stimulus, such as the cold test, giving a " hyper-reactor" response. The experiments here reported would indicate that some other factor, possibly hereditary, is responsible for the hyperreactivity of the sympathetic nervous system in certain individuals, and that such hyper-reactivity is not necessarily imposed upon a normal sympathetic nervous system by incipient or actual hypertension.

The symptoms produced by Angiotonin were usually mild, but somewhat proportional to the dosage, and to the resultant rise in arterial pressure. They resembled the complaints of patients with clinical hypertension, and help to identify such complaints as arising in actual pathologic physiology instead of being attributable to " psychoneurosis."

\section{SUMMARY AND CONCLUSIONS}

1. Angiotonin administered intravenously produces in normal subjects arterial hypertension which can be controlled by regulating the rate of administration.

2. This arterial hypertension is accompanied by an increase of venous pressure, and frequently by other signs of " myocardial failure" including:
a. Decrease in vital capacity
$b$. Increase in circulation time
c. Decrease in cardiac output
$d$. Increase in cardiac size

3. There is bradycardia, probably vagal in origin.

4. Spinal fluid pressure is not significantly altered. 
5. The electrocardiogram reveals no important changes except bradycardia.

6. The temperature of the skin usually decreases, but remains responsive to alterations of body temperature.

7. Blood flow measured plethysmographically in the limbs tends to decrease but remains under the control of the sympathetic nervous system.

8. Reactive-hyperemia blood flow (measured during full local vasodilatation produced by a 5-minute period of arterial occlusion) increases with the rise of arterial pressure.

9. The pressor response to the cold test of Hines and Brown is not altered during the hypertension.

10. Mild symptoms of dizziness, substernal oppression, headache, nausea or palpitation may be noted.

11. The effects subside 4 to 10 minutes after the cessation of administration, whether by single injection or by continuous infusion.

12. Injected intradermally, Angiotonin produces local blanching of the skin.

13. Injected intra-arterially, it produces vasoconstriction in the muscular parts supplied by the artery.

This investigation was conducted with the technical assistance of Miss Sara B. Merritt, B.S.

\section{BIBLIOGRAPHY}

1. Goldblatt, H., and others, Studies on experimental hypertension. I. The production of persistent elevation of systolic blood pressure by means of renal ischemia. J. Exper. Med., 1934, 59, 347.

2. Wood, J. E., Jr., and Cash, J. R., Experimental hypertension. Observations on sustained elevation of systolic and diastolic blood pressure in dogs. J. Clin. Invest., 1936, 15, 543.

3. Page, I. H., Production of persistent arterial hypertension by cellophane nephritis. J. A. M. A., 1939, 113, 2046.

4. Goldblatt, H., Studies on experimental hypertension. V. The pathogenesis of experimental hypertension due to renal ischemia. Ann. Int. Med., 1937, 11, 69.

5. Butler, A. M., Chronic pyelonephritis and arterial hypertension. J. Clin. Invest., 1937, 16, 889.

6. Barker, N. W., and Walters, W., Hypertension associated with unilateral chronic atrophic pyelonephritis: treatment by nephrectomy. Proc. Staff Meet. Mayo Clin., 1938, 13, 118.

7. Barney, J. D., and Suby, H. I., Unilateral renal disease with arterial hypertension. Report of a case apparently cured following nephrectomy. New England J. Med., 1939, 220, 744.

8. Stewart, C. F., Arteriosclerosis of the renal artery orifices with severe hypertension. J. A. M. A., 1940, 114, 2099.

9. Braasch, W. F., Walters, W., and Hammer, H. J., Hypertension and the surgical kidney. J. A. M. A., 1940, 115, 1837.

10. Page, I. H., Demonstration of the liberation of renin into the blood stream from kidneys of animals made hypertensive by cellophane perinephritis. Am. J. Physiol., 1940, 130, 22.

11. Houssay, B. A., and Fasciolo, J. C., Secreción hipertensora del riñón isquemiado. Rev. Soc. argent. de biol., 1937, 13, 284.

12. Kohlstaedt, K. G., and Page, I. H., Liberation of renin by perfusion of kidneys following reduction of pulse pressure. J. Exper. Med., 1940, 72, 201.

13. Fasciolo, J. C., Houssay, B. A., and Taquini, A. C. The blood-pressure raising secretion of the ischaemic kidney. J. Physiol., 1938, 94, 281.

14. Tigerstedt, R., and Bergman, P. G., Niere und Kreislauf. Skandinav. Arch. f. Physiol., 1898, 8, 223.

15. Kohlstaedt, K. G., Page, I. H., and Helmer, O. M., The activation of renin by blood. Am. Heart J., 1940, 19, 92.

16. Munoz, J. M., and others, Hypertensin: substance causing hypertension. Nature, London, 1939, 144, 980.

17. Page, I. H., and Helmer, O. M., A crystalline pressor substance (angiotonin) resulting from the reaction between renin and renin-activator. J. Exper. Med., 1940, 71, 29.

18. Braun-Menendez, E., and others, The substance causing renal hypertension. J. Physiol., 1940, 98, 283.

19. Page, I. H., The vasoconstrictor action of plasma from hypertensive patients and dogs. J. Exper. Med., 1940, 72, 301.

20. Goldblatt, H., Studies on experimental hypertension. XII. The experimental production and pathogenesis of hypertension due to renal ischemia. Am. J. Clin. Path., 1940, 10, 40.

21. Hamilton, W. F., Brewer, G., and Brotman, I., Pressure pulse contours in the intact animal. I. Analytical description of a new high-frequency manometer with illustrative curves of simultaneous arterial and intracardiac pressures. Am. J. Physiol., 1934, 107, 427.

22. Moritz, F., and von Tabora, D., Ueber eine Methode beim Menschen den Druck in oberflächlichen Venen exakt zu bestimmen. Deutsches Arch. f. klin. Med., 1910, 198, 475.

23. Hewlett, A. W., and Van Zwaluwenburg, J. G., The rate of blood flow in the arm. Heart, 1909-10, 1, 87.

24. Wilkins, R. W., and Eichna, L. W., Blood flow to the forearm and calf. I. Vasomotor reactions: rôle of the sympathetic nervous system. Bull. Johns Hopkins Hosp., 1941, 68, 425. 
25. Eichna, L. W., and Wilkins, R. W., Blood flow to the forearm and calf. II. Reactive hyperemia: factors influencing the blood flow during vasodilatation following ischemia. Bull. Johns Hopkins Hosp., 1941, 68, 450.

26. Robb, G. P., and Weiss, S., The velocity of pulmonary and peripheral venous blood flow and related aspects of the circulation in cardiovascular disease. Am. Heart J., 1934, 9, 742.

27. Starr, I., and others, Studies on the estimation of cardiac output in man, and of abnormalities in cardiac function, from the heart's recoil and the blood's impacts; the ballistocardiogram. Am. J. Physiol., 1939, 127, 1.

28. Hines, E. A., and Brown, G. E., A standard test for measuring the variability of blood pressure: its significance as an index of the prehypertensive state. Ann. Int. Med., 1933, 7, 209.

29. Freeman, N. E., The effect of temperature on the rate of blood flow in the normal and in the sympathectomized hand. Am. J. Physiol., 1935, 113, 384.

30. Hill, W. H. P., and Andrus, E. C., Effects of renin and of angiotonin upon isolated perfused heart. Proc. Soc. Exper. Biol. and Med., 1940, 44, 213.

31. Lorber, V., and Visscher, M. B., The action of angiotonin on the completely isolated mammalian heart. Am. J. Physiol. (Proc.), 1941, 133, 365.
32. Bradley, S. E., and Parker, B. A., Effect of angiotonin on circulatory dynamics. Am. J. Physiol. (Proc.), 1941, 133, 221.

33. Smith, H., Personal communication.

34. Corcoran, A. C., Kohlstaedt, K. G., and Page, I. H., Changes in arterial blood pressure and renal hemodynamics by injection of angiotonin in human beings. Proc. Soc. Exper. Biol. and Med., 1941, 46, 244.

35. Starr, I., and Schroeder, H. A., Ballistocardiogram. II. Normal standards, abnormalities commonly found in disease of the heart and circulation and their significance. J. Clin. Invest., 1940, 19, 437.

36. Starr, I., Personal communication.

37. Whitehill, M. R., Longcope, W. T., and Williams, $R$., Occurrence and significance of myocardial failure in acute hemorrhagic nephritis. Bull. Johns Hopkins Hosp., 1939, 64, 83.

38. Stead, E. A., Jr., and Kunkel, P., Influence of peripheral circulation in upper extremity on circulation time as measured by the sodium cyanide method. Am. J. M. Sc., 1939, 198, 49.

39. Wilkins, R. W., and Eichna, L. W., Blood flow to the forearm and calf. III. The effect of changes in arterial pressure on the blood flow to limbs under controlled vasodilatation in normal and hypertensive subjects. Bull. Johns Hopkins Hosp., 1941, 68, 477. 